\begin{tabular}{|c|c|}
\hline 論 文 & $\begin{array}{l}\text { TRIP 鋼の機械的性質に及ぼすマンガン } \\
\text { およびニッケルの増量の影響 }\end{array}$ \\
\hline
\end{tabular}

\author{
小林 俊郎* ·若井 直人*2 ${ }^{* 2}$ 八 渉*3 \\ 梶野 利彦 ${ }^{* 4} \cdot$ 上田 俶完 ${ }^{* 5}$
}

\title{
Effects of Manganese and Nickel Increase on Mechanical Properties of TRIP Steel
}

\author{
Toshiro Kobayashi, Naoto WAKaI, Wataru YAGI, \\ Toshihiko KAzINO and Yoshisada UEDA
}

Synopsis:

The mechanical properties such as strength, ductility, and toughness were examined in static- and dynamic-tensile tests, V-notched Charpy impact test, and dynamic fracture toughness (J-integral) test for three sorts of steels with the ausform of $25 \%$ rolling: (steel A) Fe-0.3C-9Cr-8Ni-4Mo-2Mn, (steel B) Fe$0.3 \mathrm{C}-9 \mathrm{Cr}-8 \mathrm{Ni}-4 \mathrm{Mo}-10 \mathrm{Mn}$, and (steel $\mathrm{G}$ ) Fe-0.3C-9Cr-12Ni-4Mo-10Mn.

For steel A, besides the usual TRIP in a narrow sense caused by the deformation induced $\alpha^{\prime}$-martensite, a different type of TRIP in a wide sense was observed in the static tensile test, which was due to the substructure such as stacking fault and mechanical twin. In dynamic tensile test and Charpy impact test for steel A, TRIP slightly occurred.

For steels B and C, TRIP in a wide sense alone occurred in the tests because of stabilization and low stacking fault energy of austenite matrix by high Mn content. High Mn TRIP steels provided an excellent dynamic fracture toughness.

\section{1. 緒言}

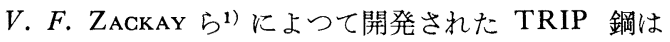
加工熱処理とその後の TRIP 現象などにより高い強度 と延性・勒性を兼備した強靶鋼であり, 各種部材として 用いられている2). その特性は化学組成および処理方法 により複雑に変化し, 必ずしも Z ACKAY ら のが最良とは限らないとの指摘もあり ${ }^{3)}$, 幾つかの改良 点も見られる4).またTRIP 現象は従来一般に静的ひず み下で準安定オーステナイトがマルテンサイトへ変態す る際に変態が徐々に進行することが必要であり高速ひず み下では早期にマルテンサイト化するために TRIP 現 象が生じにくいといわれ5)，動的ひずみ条件に関する詳 しい報告は少ない。そこで本研究では TRIP 鋼につい て静的および動的ひずみ下での材料特性の評価を行うと 共にオーステナイト安定化元素6)の $\mathrm{Mn}, \mathrm{Ni}$ を増量した
場合の影響を調べ，今後における本材のいつそうの靫性 向上の可能性について検討した.

\section{2. 実 験 方 法}

\section{$2 \cdot 1$ 供試材, 処理法および試験片}

供試材の化学組成を Table 1 に示す. 鋼Aは従来の TRIP 鋼の標準的組成 7)でありこれを基本鋼種とした. 鋼 Bは Mnを $10 \%$ に増し，鋼 $\mathrm{G}$ はさらに Ni 量を 12 $\%$ に増した. 両鋼の $\mathrm{Si}$ 量は鞀性向上をはかり $1 \%$ に 減じた。供試材は高周波大気溶解により $15 \mathrm{~kg}$ 鋼塊を溶 製し $20 \mathrm{t} \times 100 \mathrm{w} \times 250 l(\mathrm{~mm})$ に熱間鍛造したのち Fig.

Table 1. Chemical compositions of steels (wt \%).

\begin{tabular}{|c|c|c|c|c|c|c|c|c|c|}
\hline Steel & $\mathrm{C}$ & $\mathrm{Si}$ & $\mathrm{Mn}$ & $\mathrm{P}$ & $\mathrm{S}$ & $\mathrm{Ni}$ & $\mathrm{Cr}$ & $\mathrm{Mo}$ & $\mathrm{Al}$ \\
\hline $\mathrm{A}$ & 0.274 & 2.00 & 2.02 & 0.007 & 0.002 & 8.04 & 8.93 & 3.93 & 0.019 \\
\hline $\mathrm{B}$ & 0.274 & 1.04 & 10.14 & 0.007 & 0.004 & 8.07 & 8.87 & 3.94 & 0.035 \\
\hline $\mathrm{C}$ & 0.272 & 1.04 & 10.05 & 0.007 & 0.004 & 12.23 & 8.85 & 3.91 & 0.050 \\
\hline
\end{tabular}

昭和 56 年 11 月日本金属学会講演大会にて一部発表 昭和 59 年 9 月 3 日受付 (Received Sep. 3, 1984)

* 豊橋技術科学大学工学部工博 (Faculty of Engineering, Toyohashi University of Technology)

*2 名古屋大学大学院 (現：(株) 東芝) (Graduate School, Nagoya University, Now

Toshiba Co., Ltd.)

*3 名古屋大学大学院 (現：アイシン精機(株)) (Graduate School, Nagoya University, Now Aisin Seiki Co., Ltd.)

*4 鈴鹿工業高等専門学校 (Suzuka Technical College, Shiroko-cho Suzuka 510-02)

*5 名古屋大学工学部工博 (Faculty of Engineering, Nagoya University) 


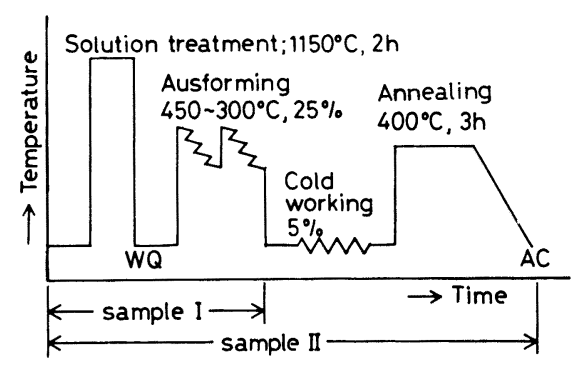

Fig. 1. Schematic diagram of heat treatment and thermo-mechanical process.

(a)

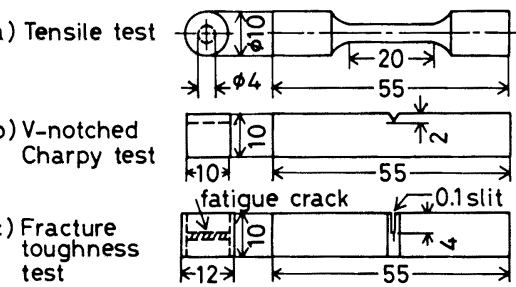

Fig. 2. Geometries of specimens.

1 に示す処理を施した.オースフォームは小型圧延機を 用い約 10 pass， 2 heat で行つた。これまでの試料をI 材とし供試材記号を AI，BI，CI とした。藤田ら出によ ればこれに続くサブゼロ処理は衝撃勒性を劣化するので 本研究では用いなかつた．室温での小型圧延機による冷 間加工と加工ひずみ除去焼なましを付加した試料をII 材

(AII，BII，CII) とした。各種の試験片 (Fig. 2) は長 手方向を压延方向に，切り欠きを板厚方向にして機械加 エした。

\section{$2 \cdot 2$ 組織観察とマルテンサイトの定量}

組織観察はバフ研磨・電解研磨ののち $1 \%$ ピクリン 酸アルコール溶液-塩酸の $100: 15$ の混合溶液で腐食し 光学顕微鏡によつた． $\alpha^{\prime}$ および $\varepsilon$ マルテンサイトは $\mathrm{MILLER}^{8)}$ (回折線：(211) $\left.\alpha^{\prime},(220)_{\gamma},(311)_{\gamma}\right)$ 拈よび $\operatorname{REED}^{59)}\left((10 \overline{1} 1)_{\varepsilon},(200)_{\gamma},(200)_{\alpha}\right)$ のX 線回折法で 定量した。

\section{$2 \cdot 3$ 材料試験}

引張試験は $-196 \sim 90^{\circ} \mathrm{C}$ において，静的試験はイン ストロン型試験機を用いクロスヘッド速度 $0.1 \mathrm{~mm} / \mathrm{min}$ $\left(\dot{\varepsilon}=8 \times 10^{-4} \mathrm{~s}^{-1}\right)$, 動的試験は容量 $490 \mathrm{~J}$ の計装化シ ヤルピー試験機を用いハンマー速度 $5 \mathrm{~m} / \mathrm{s}\left(\dot{\varepsilon}=250 \mathrm{~s}^{-1}\right)$ で行つた、シャルピー衝撃試験は $-196 \sim 200^{\circ} \mathrm{C}$ におい て動的引張試験と同じ試験機・速度で実施 乙, 荷重-変 位曲線から吸収エネルギー・最大荷重などを演算装置 ${ }^{10)}$ を用いて算出した．動的破壊勒性試験は計装化シャルピ
一試験機を用い low blow 法 ${ }^{10)}$ (容量 $49 \mathrm{~J}$, 衝撃速度 $1.7 \mathrm{~m} / \mathrm{s})$ で実施し，コンプライアンス法10) で補正した 荷重一変位曲線から安定き裂発生エネルギーを求め RICE の式11 とより $J$ 積分值を求めた. この場合 stop block 法12) · 加熱着色法により, き裂進展量と変位量の関係を 求め, ミク口破面上での限界ストレッチゾーン幅との対 応から安定き裂発生点を決定した。

\section{3. 実験結果および考察}

\section{$3 \cdot 1$ ミクロ組織}

各試料の光学顕微鏡組織をオーステナイトの平均粒径 $\left(d_{r}\right)$ ·硬さ $(\mathrm{HV}, 490 \mathrm{~N})$ と共に Photo. 1 亿示す. 各 試料之も基地はオーステナイトであり， $d_{\gamma}$ は鋼 $\mathrm{A}$ の約 $25 \mu \mathrm{m}$ に比へ，鋼BとCではそれぞれ約 56, 65 73 $\mu \mathrm{m}$ と $\mathrm{Mn} ， \mathrm{Ni}$ の添加により粗大化した，基地中に黒く点 在する相はX線マイクロアナライザーによる調查から未 固溶の Mo 炭化物と思われる。試料 AII KはX線回折 に上り約 $10 \%$ の $\alpha^{\prime}$ マルテンサイトが検出されたが他 の試料には認められなかつた．鋼 $\mathrm{A} の \mathrm{M}_{\mathrm{d}}$ 点は室温以上 であり室温加工によつて加工誘起 $\alpha^{\prime}$ マルテンサイトが 生じたことがわかる.

オーステナイト粒内にすじ状模様が見られ特に鋼 B $\mathrm{C}$ で著しく，また I 材よりもII材で幾らか多くこの点は 硬さに反映されている。このすじ模様は $\varepsilon$ マルテン+イ 卜との推定も市る4)。積層欠陥エネルギーの低い fcc 鋼においては下部組織として積層欠陥・変形双晶 $\cdot \varepsilon$ マ ルテンサイトの存在が考光られ，M. W. BOWKETT ら ${ }^{13)}$ は $18 \mathrm{Cr}-8 \mathrm{Ni}$ 鋼においてこれらの下部組織が共存する 例を認めているが，本実験の供試鋼についてのX線回折

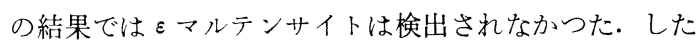
がつてミクロ組織に見られたすじ模様は変形双晶と及な される。

\section{$3 \cdot 2$ 引張特性}

$3 \cdot 2 \cdot 1$ 室温特性

室温での静的引張試験の結果を Table 2 に示す. 鋼 $\mathrm{A}$ の引張強さ（オースフォーム加工率 $25 \%$ で $1 \mathrm{GPa}$ ) は従来の報告と比較すると Z ACKAY ら $ら^{1)}$ の最高值（同 $80 \%$ で $2 \mathrm{GPa}$ ) の約 $1 / 2$, 藤田ら ${ }^{4}$ ) の結果（同 $35 \%$ で $1.3 \mathrm{GPa}$ よりも幾らか低く，オースフォームによる 加工硬化の影響が大きい、鋼 $\mathrm{B}$ と C の強度は同一処理の 鋼A に比べ 10〜20\% 泀ど低いが，これは $\mathrm{Mn}, \mathrm{Ni} の$ 增量によつて積層欠陷が生じやすく転位が拡張するため いわゆる加工硬化の第 2 段階において，交差すべりが起 こりにくくなり転位運動を阻害するもつれた転位やセル 壁の形成が少ないことと， $d_{r}$ が鋼 $\mathrm{A}$ に比べ約 2 倍以上 


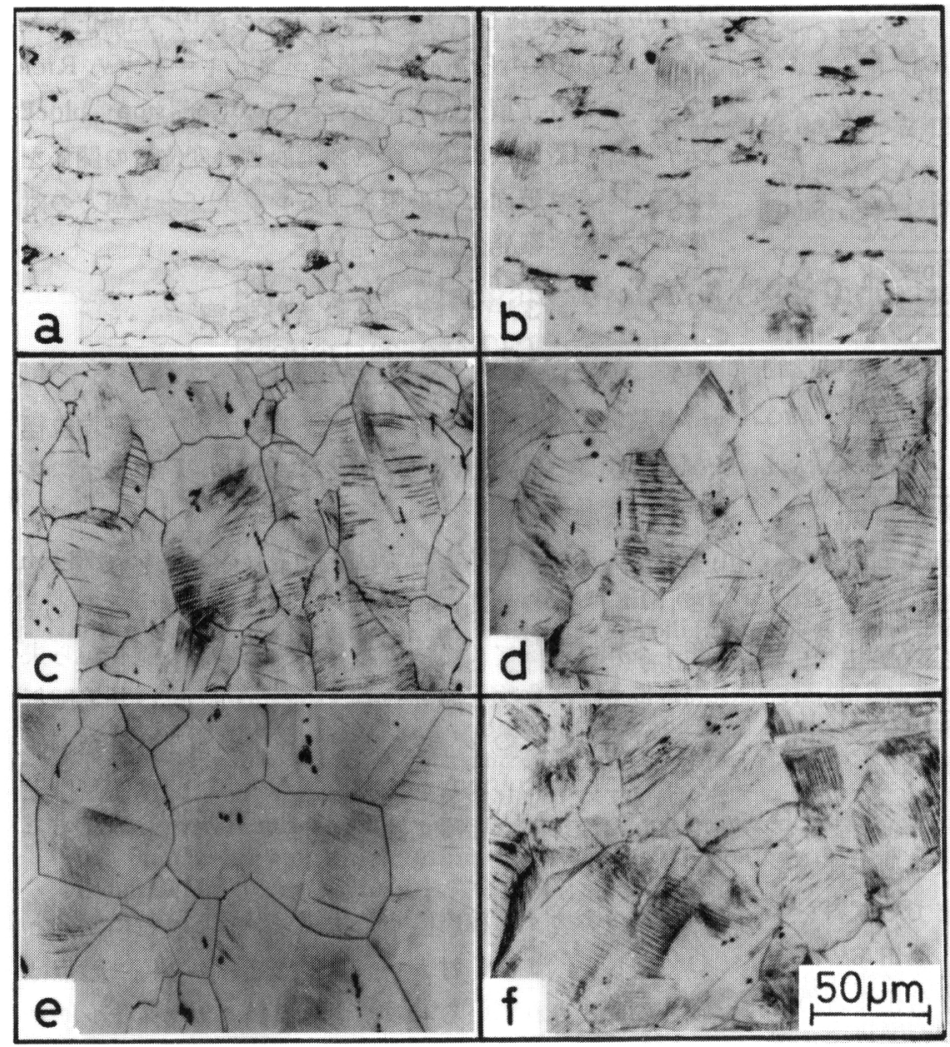

naterial, $d_{\gamma}(\mu \mathrm{m}), \mathrm{HV}(490 \mathrm{~N})$

$\begin{array}{ll}\text { a) } \mathrm{A} \mathrm{I}, 25,330 & \text { b ) } \mathrm{AII}, 27,390\end{array}$

c ) $\mathrm{B} I, 56,303 \quad$ d ) $\mathrm{BII}, 57,330$

e ) $\mathrm{C} I, 65,303 \quad$ f ) $\mathrm{CII}, 73,330$

Photo. 1. Microstructures of materials with austenite grain size $\left(d_{\gamma}\right)$ and Vickers hardness (HV).
Table 2. Static tensile properties of materials at $25^{\circ} \mathrm{C}$

\begin{tabular}{l|r|r|r|r|r|r}
\hline Steel & \multicolumn{2}{|c|}{ A } & \multicolumn{2}{c|}{ B } & \multicolumn{2}{c}{ C } \\
\hline Process & I & II & I & II & I & II \\
\hline$\sigma_{0.2}(\mathrm{MPa})$ & 813 & 1019 & 744 & 804 & 794 & 833 \\
\hline$\sigma_{B}(\mathrm{MPa})$ & 1068 & 1225 & 931 & 1019 & 862 & 970 \\
\hline EL $(\%)$ & 39 & 22 & 40 & 31 & 34 & 28 \\
\hline RA $(\%)$ & 39 & 26 & 64 & 64 & 67 & 63 \\
\hline
\end{tabular}

$\sigma_{0.2}: 0.2 \%$ proof stress, $\sigma_{B}$ : tensile strength

EL : total elongation, $\mathrm{RA}$ : reduction of area

に大きいことも一因と考えられるまたどの鋼種でも II 材の方が約 $10 \%$ 高い強度を示しており $5 \%$ 室温加工 による加工強化は必ずしも小さくはない。

一方，延性についてはI 材はどの鋼種も30\% 以上の 伸びを示したが，II材では鋼 B と Gで約 $25 \%$ ，鋼 Aで は約 $15 \%$ と低減した. 断面収縮率は鋼A 亿比較して鋼 B と G I ，II材とも $60 \%$ 以上の高い值を示し， Mn の増量による効果が大きく，これの靱性への寄与が予期 される.

\section{$3 \cdot 2 \cdot 2$ 試験温度・ひずみ速度の影響}

従来, 静的引張試験での TRIP による伸び (EL)の ピークは $\mathrm{M}_{\mathrm{s}} \sim \mathrm{M}_{\mathrm{d}}$ 間で見られ, その時の耐力 $\left(\sigma_{\mathbf{0} .2}\right)$ はほぼ一定であるが引張強さ $\left(\sigma_{B}\right)$ は降温に伴い漸増す るといわれている14). このよ5な TRIP 鋼の特徵は Fig. 3 に示した鋼Aについての静的引張特性の温度に よる変化曲線にも認められる。鋼 A についてはさらに

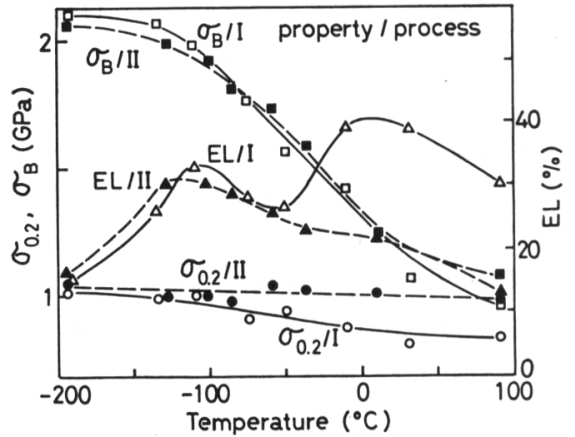

Fig. 3. Temperature dependence of $0.2 \%$ proof stress $\left(\sigma_{0.2}\right)$, tensile strength $\left(\sigma_{B}\right)$ and total elongation (EL) for steel $\Lambda$ in static tensile test. 


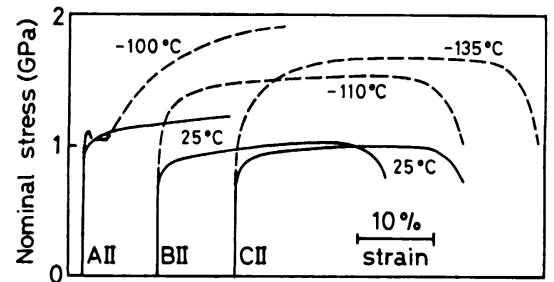

Fig. 4. Nominal stress-strain curves for materials $\mathrm{AII}, \mathrm{BII}$ and $\mathrm{CII}$ in static tensile test at $25^{\circ} \mathrm{C}$ and low temperature.

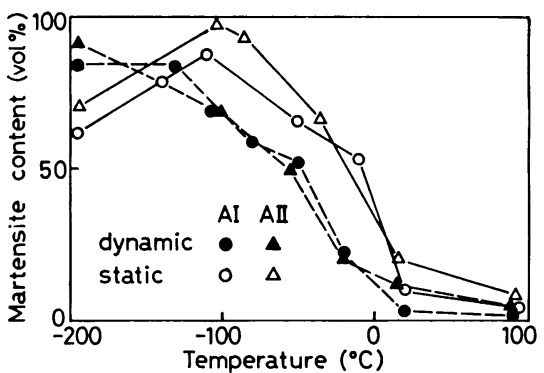

Fig. 5. Temperature dependence of strain induced $\alpha^{\prime}$-martensite for steel $\mathrm{A}$ in static and dynamic tensile test.

TRIPに関連する現象が応力ーひずみ曲線上にも見られ た (Fig. 4). 寸なわち, 約 $-10^{\circ} \mathrm{C}$ 以下で明瞭な降伏 現象が見られたこれは一般に bcc 金属には見られる が fcc では起こらないから， $\gamma \rightarrow \alpha^{\prime}$ 変態が加工誘起さ れたことに対応している. また加工誘起 $\alpha^{\prime}$ マルテンサ イトの生成に伴い加工硬化率が増し, 塑性不安定が生じ るまでの均一伸びが大きく現れ，くびれを起こしにくい などの特徵もFig. 4 の鋼 A の応力ーひずみ曲線に見る とおりである. また引張試験後の試験片の均一伸び部に ついてX線回折によつて測定した加工誘起 $\alpha^{\prime}$ マルテン サイト量の温度による変化を Fig. 5 に示す. 静的引張 による $\alpha^{\prime}$ 量が $-100^{\circ} \mathrm{C}$ 以下で減少したのは, 低温で はくびれ部などの影響もあり変形量が十分にならないら ちに早期破断するためと思われる．以上に見たように鋼 Aについては加工誘起変態 $\alpha^{\prime}$ マルテンサイトが生成 し，それに起因する TRIP が Fig. 3 の伸び曲線上の 約 $-100^{\circ} \mathrm{C}$ でのピークに反映されていると考えてよい が, 試料 A I の伸び曲線は $0^{\circ} \mathrm{C}$ 近くの高温側にもら ひとつのピークが認められる. Fig. 5 に見るとおり0 ${ }^{\circ} \mathrm{C}$ 以上での A I 材の $\alpha^{\prime}$ マルテンサイト量は少な く， $\alpha^{\prime}$ 量がほぼ同量の A II 材ではこのピークが生じ ていない点を考え合わせると，このピークは従来の $\alpha^{\prime}$ マルテンサイトによる TRIP ではないといえる. A I 材はオースフォームのみであり加工硬化の程度が A II
材に比べて低いため， $\alpha^{\prime}$ マルテンサイトの生成に先立つ すべり変形中での積層火陷や変形双晶の発生が容易と考 えられる。これらは局所的な転位運動を抑制するが，そ の周辺での平行なすべり面上でのすべり変形はもしろ増 進し伸びは著しく増大寸る.なお積層欠陥・変形双晶の 存在下では，それらと転位の交切部に $\alpha^{\prime}$ マルテンサイ トの核生成が起こるといわれており ${ }^{15)}$ このようにして 生じた $\alpha^{\prime}$ も TRIP に寄与するが，ここでの程度は小 さい．以上に見たように加工に伴う大きな塑性は従来の $\alpha^{\prime}$ マルテンサイトによるもの（狭義の TRIP）とは別 に，積層欠陥・変形双晶に起因するものがあり，以下で はこれを広義の TRIP と呼ぶことにする.

次に動的引張試験の結果については荷重-変位曲 線が 振動波により大きく乱れ諸特性値の解析が困難であつた ので，試験片上で求めた全伸びと断面収縮率について試 験温度による変化を静的特性と共に Fig. 6 にまとめて 示す. 鋼 $\mathrm{A}$ の動的伸びは, $0{ }^{\circ} \mathrm{C}$ 以上での A I 材の静的 伸びを除けば，むしろ静的伸びょりも高く $-100^{\circ} \mathrm{C}$ 以 トでも低下していない，一方 Fig. 5 にみるように動的 引張りによる $\alpha^{\prime}$ マルテンシサイト量の曲線は静的なもの に比べ低温側へ移行しており，これは高速ひずみ下では 変形に伴ら温度上昇によつて $\gamma-\alpha^{\prime}$ 変態が抑制されるた めと考元られ ${ }^{16)}$, 動的伸びの高い值が従来の TRIP に よるとは考えにくい，したがつてこれは高速ひずみ下で の変形双晶の発生しやすいことに基づく広義の TRIP

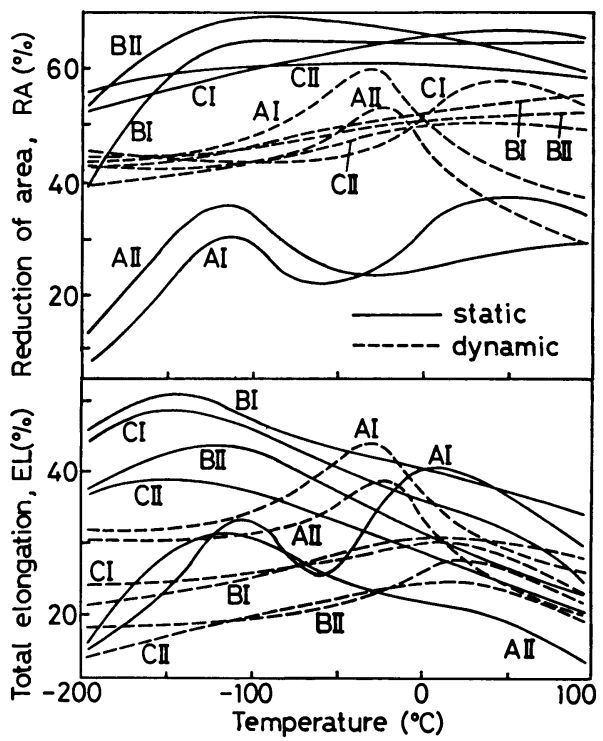

Fig. 6. Temperature dependence of total elongation and reduction of area for materials in static and dynamic tensile test. 
によるものと考党られ，-30C 付近の動的伸びのピー クは $-100^{\circ} \mathrm{C}$ 近くの静的伸びのピークが高温側へ移行 したといらよりはむしろ A I 材についての $0^{\circ} \mathrm{C}$ 近く のピークが低温側へ移行したとみなされる.なお鋼Aの 動的伸びは他鋼のものよりも大きいことより，鋼Aにお いては広義の TRIP と共に狭義の TRIP もある程度 は伸びに寄与していると考える。また動的引張試験では 局部しぼりが生じ，断面収縮率は静的なものに比べて高 くなつた。これは他鋼には見られない特徵である.

次に鋼 B と $\mathrm{G} の$ 伸びと断面収縮率の温度による変化に ついて述べる. 静的伸びは降温に伴い漸増し $-196^{\circ} \mathrm{C}$ 近くでやや低下する. 一方動的伸びは高温側では静的伸 びと大差ないが室温以下ではむしろ漸減する。ここで鋼 B， C は高 Mn fec 鋼であり White と Honeycombe ${ }^{17)}$ のいう $\gamma \rightarrow$ 積層欠陥 $\rightarrow \varepsilon \rightarrow \alpha^{\prime}$ の変化によるマルテンサイ トの生成が予測されたが，引張試験後のX線回折の結果 $\alpha^{\prime} ， \varepsilon$ マルテンサイトのいずれも検出されなかつた。 た応力ーひずみ曲線も Fig. 4 にみるよらに降伏を起こさ ず，加工硬化率が小さく，また局部しぼりが発生した点 などからすると従来の TRIP は起こらなからたとい光 る.したがつて鋼 B， Cに見られる大きな塑性は，すで に A I 材について触れたと同様に広義の TRIP によ るものと考无られる.な拈高 Mn 鋼に打ける動的ひず

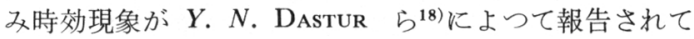
いるが，本鋼の場合は炭素量が低いため考兄にくい、鋼 $\mathrm{B}, \mathrm{C}$ においては $\mathrm{Mn}, \mathrm{Ni}$ の増量によつて $r$ 基地が化学 安定化されたため，かなりの低温まで高い静的伸びが維 持された. 他方動的伸びの低下については次のように考 えている，高速ひずみ下では双晶変形が促進されるが， 動的引張り下では局部くびれが生じやすいため広義の TRIP がくびれ部近くに制約され十分な伸びを生じない らちに早期破断が起こる。また静的伸びについては鋼種 および室温加工の有無による差異がみられるが（動的な 場合には鋼種による違いは明瞭でない)，鋼 Cでは Ni の増量による積層欠陷発生頻度の低下， II 材では可動転 位密度の低下がおもに影響したと考える。鋼 B，Gにつ いての引張試験に打いては局部しぼりが発生し，その周 辺での広義の TRIP 現象により断面収縮率は 40〜70 \%の大きな值を呈し, 静的なものの方が動的なものよ り高い値を示したが，温度による変化は小さい。また鋼 種および処理の違いによる変化は互いに入り組んでお り，くびれ部に拈ける 3 軸応力下の広義の TRIP の複 雑さがらかがわれる。

\section{$3 \cdot 3$ シャルピー衝撃特性}

各試料について計装化シャルピー衝撃試験で得られた
荷重一変位 $(P-\Delta)$ 曲線から求めた最大荷重 $\left(P_{m}\right)$, 全吸 収エネルギー $\left(E_{t}\right)$ および $P_{m}$ までのエネルギー $\left(E_{i}\right)$ の試験温度による変化を Fig. 7 に示す. 全体的な傾向 として，降温すると $P_{m}$ は漸増し， $E_{t}$ は漸減するが bcc 材にみられるような明瞭な遷移挙動を示さず， $E_{i}$ は鋼 $\mathrm{A}$ 以外は漸増する。以下, 各鋼の特徵を述べる.

鋼 $\mathrm{A} の E_{t}$ 曲線上に A I では約 $-70^{\circ} \mathrm{C}$, AII では 約 $-65^{\circ} \mathrm{C}$ でピークが認められ, 同様のピークが $E_{i}$ 曲 線上にもみられる. 従来 $\mathrm{Fe}-\mathrm{Ni}-\mathrm{Mn}$ 系ステンレス鋼な どのシャルピー衝撃值が $\mathrm{M}_{\mathrm{s}} \sim \mathrm{M}_{\mathrm{d}}$ 間で TRIP によるピ ークを示す現象は認められている19). 鋼Aについては引 張試験でも加工誘起変態を認めたので，このピークが TRIP に関係すれば破面近くに加工誘起マルテンサイト

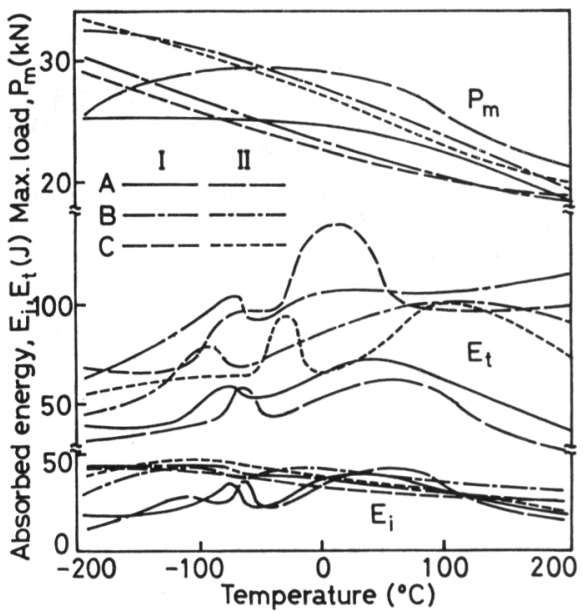

Fig. 7. Temperature dependence of maximum load $\left(P_{m}\right)$, total absorbed energy $\left(E_{t}\right)$ and energy to maximum load $\left(E_{i}\right)$ for materials in Charpy impact test.

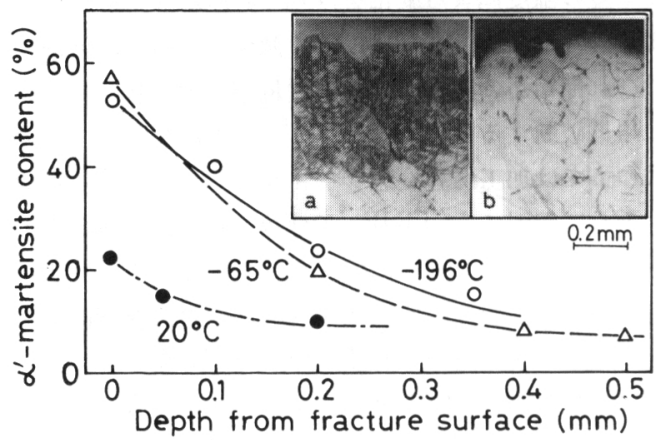

Fig. 8. Formation of strain induced $\alpha^{\prime}$-martensite nearby fracture surface for material AII in Charpy impact test and fracture surface profiles at -196 (a) and $20^{\circ} \mathrm{C}$ (b). 


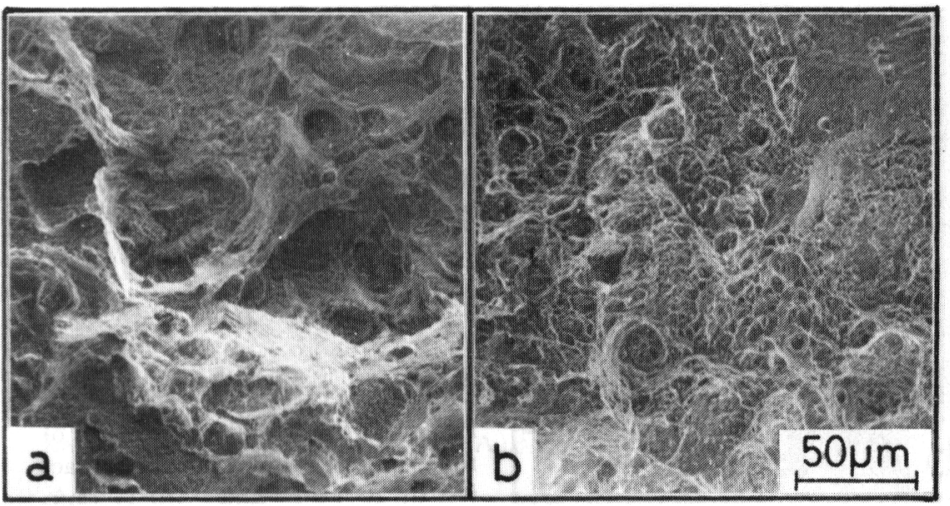

Photo. 2. SEM /micro-fractographs of material A II in Charpy impact test at 20 (a) and $-65^{\circ} \mathrm{C}$ (b).
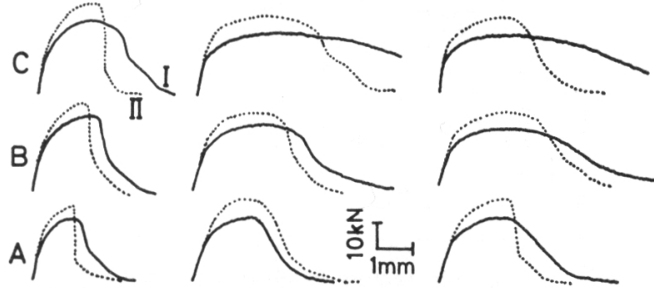

Peak temp.

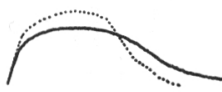

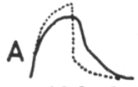

$-196^{\circ} \mathrm{C}$

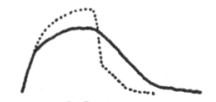

$20^{\circ} \mathrm{C}$
Fig. 9. Load-deflection curves for materials in Charpy impact test at several temperatures.

が存在するはずである，そこで試料 AII について破面 中央部に拈いて表面から種々の深さの所の $\alpha^{\prime}$-マルテン サイト量をX線回折法によつて調べた結果を Fig. 8 に 示す。 -196 と $-65^{\circ} \mathrm{C}$ (ピーク温度) での破面直下の $\alpha^{\prime}$-マルテンサイト量は約 $60 \%$ であり, 深さと共に減少 し約 $0.5 \mathrm{~mm}$ の所まで認められた. $20^{\circ} \mathrm{C}$ での最大量は 約 $20 \%$, 変態深さは約 $0.2 \mathrm{~mm}$ である. 屯た同図中に 示した破面の縦断面でのミク口組織上で求めたマルテン サイト変態域は $-196^{\circ} \mathrm{C}$ について約 $0.4 \mathrm{~mm}$ であり, X線回折による結果とほぼ一致した $\left(20^{\circ} \mathrm{C}\right.$ のものには 明瞭には認められなかつた)。またミク口破面観察によ れば, Photo. 2 に示したよらに $20^{\circ} \mathrm{C}$ では一般的な等 軸ディンプルの延性破面であるのに対し， $-65^{\circ} \mathrm{C}$ では 加工誘起マルテンサイトに起因すると考光られる微細な ディンプルが認められる.さらに Fig. 9 に示した $P-\Delta$ 曲線についてもピーク温度では延性が大きく現れてお り，TRIP 現象が反映していると考觉られる．これらの 点から鋼 A はシャルピー衝撃試験においてもある温度域 で狭義の TRIP を起こすが, 切り欠きによる応力集中 が高速変形のためにごく狭い範囲に限定され, また加工 誘起マルテンサイト自体の延性が乏しいため十分な靱性 の向上を示寸に至らなからたと考えられる.
次に鋼 Bについても $E_{t}$ 曲線上に約 $-70^{\circ} \mathrm{C}(\mathrm{BI})$ と 約 $-100^{\circ} \mathrm{C}(\mathrm{B} I I)$ でピークがみられる. しかし $E_{i}$ 曲線 は鋼A とは異なり一様に変化しており，また $P-\Delta$ 曲線 での $P_{m}$ 以後の変位が特に大きく, き裂伝播過程での 吸収エネルギーとの関連が考学られる.破面近くについ てのX線回折の結果, どの温度のものからもマルテンサ イトは検出されなかつた。 またミクロ破面のディンプル は絞られて抢り靶性の高いことがらかがわれたが，鋼 A のピーク温度でみられた微細ディンプルは認められなか つた. したがつて鋼 $\mathrm{B} の E_{t}$ 曲線上のピークは従来の TRIP によるものではないといえる. また鋼 $\mathrm{C} の E_{t}$ 曲 線上には $-10^{\circ} \mathrm{C}\left(\mathrm{C}\right.$ I ) と $-30^{\circ} \mathrm{C}(\mathrm{C}$ II $)$ にピークが生 じた.ピークの高さと幅は他鋼に比べて大きく, 特に試 料 G I のものは著しい.これは $P-\Delta$ 曲線上の変位が 特に大きく，き裂伝播に対する抵抗が優れていることに よる. 他の特徴は鋼 B と類似しており, 加工誘起マルテ ンサイトは検出されなかつた.

ここで試料 B I の室温とピーク温度におけるシャル ピー衝撃試験後の試料から薄膜を作成し透過型電子顕微 鏡により観察した結果を Photo. 3 に示す. ピーク温度 のものは下部構造の変化が著しい. これは積層欠陥・変 形双晶とみなされるが詳細は今後の課題である. したが つて高 Mn の鋼 B， C ではシャルピー衝撃試験の場合 にも積層欠陥・変形双晶のような下部構造に起因する広 義の TRIP が起こり, それに伴い吸収エネルギーが向 上したと考帛る. この場合, 引張試験の結果にみられた 大きな断面収縮が衝撃試験の場合にはリガメント部にお ける収縮変形として現れるよらになり, その部分での広 義の TRIP によつて $P_{m}$ 後での変位の増大と荷重が低 下しにくい特徴を生じた、な打鋼 B， Cの吸収ェネルギ 一曲線上のピークは広義の TRIP に関し, 双晶変形は 低温ほど生じやすいが転位運動は逆に起こりにくくなる 


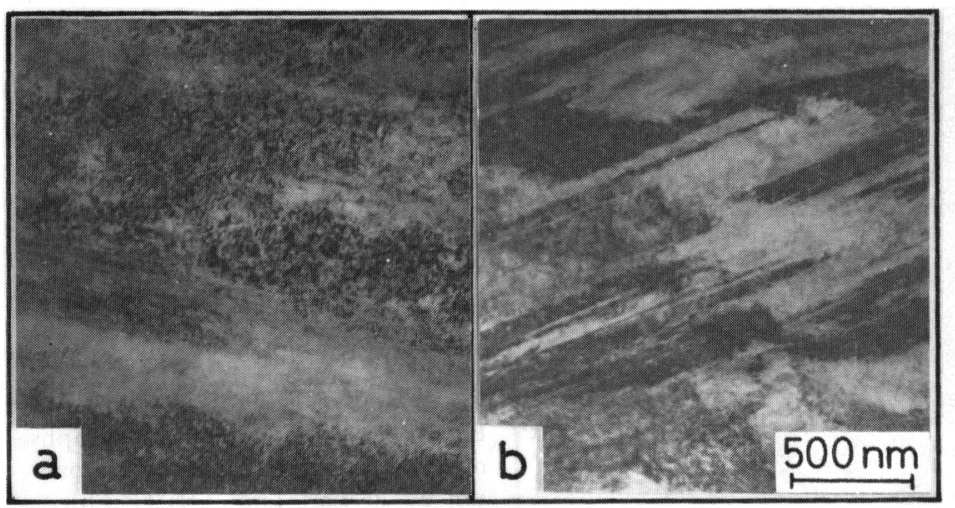

Photo. 3. TEM microstructures of material B I in Charpy impact test at 20 (a) and $-70^{\circ} \mathrm{C}$ (b).

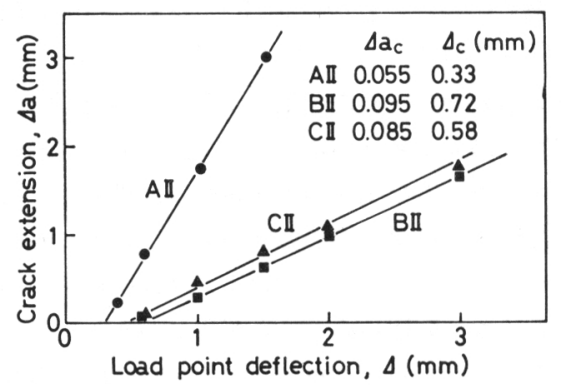

Fig. 10. Relation between crack extension and load point deflection in low blow test using stop block.

ため, 両方がうまくバランスする温度域が存在するため に生じたと考觉る.さらに鋼 $\mathrm{C}$ は $\mathrm{Ni}$ 量が多く積層欠陥 エネルギーが高いため試験前での積層欠陥・変形双晶が 少なく, また試験時でのこれらの発生も軽少のため, む しろ変形しやすいことと, き裂伝播が変形双晶を通して 進行することも考光られ，この場合には変形双晶が少な い鋼 C特に G I 材で勒性が向上するよらになる。この 広義の TRIP は鋼の組成拉よび処理法を調節すること で勒性の向上に関し有効であることを示唆しており, 今 後注目すべきである.

\section{4 動的破壊䩓性}

鋼 $\mathrm{A} ， \mathrm{~B}$ 抒よび $\mathrm{C} の I I$ 材について, stop block-low blow test で得られた, き裂進展量 $(\Delta a)$ と荷重点変

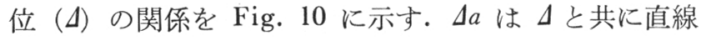
的に増大し, 同一の $\Delta$ 值に対する $\Delta a$ 値の比較から, 鋼 Aが最もき裂が進展しやすく, ついで鋼 $\mathrm{C}, \mathrm{B}$ の順であ る.この点から鋼 $\mathrm{B}$ の破壊勒性が高いことが示唆され る. 安定き裂発生点までの $\Delta a$ 值 $\left(\Delta a_{e}\right)$ は SEM フラタ トグラフィ法で求めた限界ストレッチゾーン幅 $\left(\mathrm{SZW}_{c}\right)$ より算出し ${ }^{9)}$, Fig. 10 にお梳る $\Delta a-\Delta$ 直線上で $\Delta a_{c}$ 值

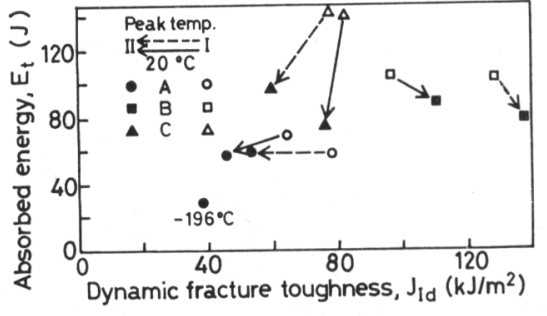

Fig. 11. Relation between dynamic fracture toughness and Charpy absorbed energy for materials.

に対応する $\Delta$ 值 $\left(\Delta_{c}\right)$ を求め同図中に示した. 次に $P-\Delta$ 曲線から算出されるひずみエネルギーについては， $\Delta_{c}$ 要 での值を $E_{i}^{\prime}, P_{m}$ までの值を $E_{i}$ とし, 両者が $E_{i}^{\prime}=k E_{i}$ の関係にあるとして各試料について係数 $k$ を求めた結 果, $\mathrm{A} I I I: 0.70, \mathrm{~B} I I: 0.80, \mathrm{C}_{I I}: 0.65$ であつた. $k$ 值 は処理や試験温度などによつて異なることが推測される が,ここでは近似的に同一鋼種で一定とみなし, 各鋼の I 材および異なる温度についての $E_{i}^{\prime}$ の值を求め, RICE の式10)を用いて J積分值を算出した. 各鋼の I, II 材 についての室温およびシャルピー衝撃値のピーク温度に 扔いて求めた $J$ 值は，すべて $\mathrm{PARIS}^{20)}$ ， LANDES ${ }^{21)}$ の平面 ひずみ条件式を満たし，有効な動的破壊勒性值 $\left(J_{\mathrm{Id}}\right)$ である・このようにして得られた $J_{1 d}$ をシャルピー衝 撃值（全吸収エネルギー: $E_{t}$ ) との相関において Fig. 11 飞示す. 室温での $J_{1 d}$ は同一処理材で比較すると鋼 B が最も優れ，鋼 $\mathrm{C}, \mathrm{A}$ の順であり,この傾向は $E_{t}$ そつい ても浪涪同様である。したがつて TRIP 鋼中の Mnの 增量はV 切り欠き靱性のみならず破壊靱性の向上飞も有 効である. またI材とII材との比較から，オースフォー 厶後の冷間加工によつて $E_{t}$ はどの鋼でも減少するが (減少程度は鋼 $\mathrm{A}, \mathrm{B}, \mathrm{C}$ の順に大きい)，J $J_{1 d}$ は鋼 $\mathrm{A}$ と $\mathrm{C}$ では減少するものの鋼 $\mathrm{B}$ では逆に増大寸る点が特記さ 
れる. 他方，ピーク温度における $J_{I d}$ は鋼 $\mathrm{A}$ と B では 室温よりも向上したが, 鋼Cでは低下した.なお $E_{t}$, $J_{\mathrm{I} d}$ に及ぼす冷間加士の影響は室温の場合と同様である. このように $E_{\iota}$ および $J_{1 d}$ は鋼種・処理法・試験温度 によつて複雑に变化し,このことより切欠先端半径が異 なると応力集中の程度および積層欠陷や变形双晶のよう な下部組織の情況が複雑に変化することが推測される が, 詳細は今後の課題である.

\section{4. 結言}

ZACKAY らの提唱した TRIP 鋼(A)および Mnを 10\%に増量した鋼(B)さらに Ni を $12 \%$ に增した鋼 (C)に压下率 $25 \%$ のオースフォームさらに $5 \%$ 冷間加 工を施した試料について, 強度・延性・鞖性を種々の温 度における各種試験によつて評価し，次のような結論を 得た。

1) 鋼 $\mathrm{A}$ は静的引張試験において加工誘起マルテンサ イトに起因する従来のTRIP 現象のほかに処理法によ つては積層欠陥・変形双晶によると考元られる TRIP が認められ前者を狭義の TRIP, 後者を広義の TRIP と区別することが提案される. 動的引張試験ではむしろ 高い伸びが見られ広義の TRIP が優勢のよらである.

2) 鋼 B， Cについても広義の TRIP による高い延 性が静的引張試験で認められたが，局部しぼりが生じや すいため動的試験では TRIP は局所的になり伸びは低 i.

3) シャルピー衝撃特性についても鋼 $\mathrm{A}$ では狭義の TRIP また鋼 B， G では広義の TRIP に起因する吸収

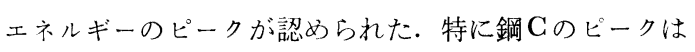
他鋼に比べ大きく, $\mathrm{Mn}, \mathrm{Ni}$ の増量による衝撃靸性の向 上が示唆された。

4) stop block, low blow test, フラクトグラフィ法 によつて安定き裂発生点を決定して求めた動的破壊靱性 值はすべて有効な值 $\left(J_{\mathrm{I} d}\right)$ であつた。鋼 $\mathrm{B} の J_{\mathrm{I} d}$ は ほかに比べて優れ，Mnの増量が破壊靱性の向上に効果 がある・

5 ) 処理法における冷間加工の付加は強度が増寸反面
で延性・靱性を低下させる.

最後に実験の遂行に協力された名古屋大学丁学部学生 志賀雅治君（現・新東工業(株)）並びに試料の溶製に御 協力いただいた日本治金丁業(株)に対し深甚なる媩意を 表します。

\section{文献}

1) $V . F . Z_{\text {AckAy, }} E \cdot R \cdot$ PARker, D. FAhr and R. Busch: Trans. ASM, 60 (1967), p. 252

2 ) E. D. Dulis and $V . K$. Chandhok: Met. Prog., 95 (1969), p. 101

3 ) 田村今男：鉄と鋼, 56 (1970), p. 429

4 ) 藤田 達, 三沢博上, 堤 汇永: 鉄と鋼, 58 (1972), p. 1693

5 ) 田村今男, 牧正志: 鋼の強靶性 (1971), p. 185 [Climax Molybdenum Development Company (Japan) Ltd.]

6 ) 田村今男：鉄鋼材料強度学 (1969), p. 51 [日刊 工業新聞社:]

7 ) $W . W$. Gerberich, $P . L$. Hemmings, $M . D$. MERz and $V$. F. ZACKAY: University of Calif., Berkeley, UCRL-18609 (1968)

8 ) R. L. Miller: Trans. ASM, 57 (1964), p. 892

$9)$ R. P. Reed and C. J. Guntner: Trans. Metall. Soc. AIME (1964) 230, p. 1713

10）小林俊郎，松原 等, 上田俶完：鉄之鋼，67 (1981), p. 2216

11) J. R. Rice, P. C. Paris and J. G. Merkle: ASTM STP 536 (1973), p. 231

12) 小林俊郎, 松原 等, 藤井齐, 上田俶完: 鉄之 鋼, 68 (1982), p. 1839

13) $M . W$. Bowkett, $S . R$. Keown and $D . R$. Harries: Met. Sci., 16 (1982), p. 499

14) 田村今男, 牧正志, 波户 浩, 油井孝輔: 日本 金属学会誌, 33 (1969), p. 1383

15) L. E. Murr, K. P. Staudhammer and $S . S$. Hecker: Metall. Trans., 13A (1982), p. 627

16) S. S. Hecker, M. G. Stout, K. P. Staudhammer and $J$. L. Smith: Metall. Trans., 13A (1982), p. 619

17) C. H. White and P.W. K. Honeycombe: JISI, 202 (1962), p. 457

18) $Y . N$. Dastur and $W . C$. Leslie: Metall. Trans., 12A (1981), p. 749

19）須藤 一：日本金属学会会報，14 (1975), p. 681

20) P. G. PARIS: ASTM STP 514 (1972), p. 21

21) $J$. D. Landes and $J$. A. Begley: ASTM STP 560 (1974), p. 170 